\title{
Anthony Pym*
}

\section{Humanizing Translation History}

\begin{abstract}
The structuralist principles of systems-based Translation Studies tend to conceal the social roles played by translators in mediating between cultures. Attention to slightly alternative principles might be able to initiate a progressive humanization of Translation Studies, possibly alerting scholars to phenomena previously overlooked. Two such principles are illustrated here on the basis of Hispanic translation history. First, if attention is paid to translators and only then to the texts they produce, the subjectivities thus revealed tend to display multidiscursive involvement (translators usually do more than translate), complex cultural allegiances (they are not always faithful or loyal to one side), and physical mobility (they tend not to not stay in just one place). The second idea is that translators can be seen as operating in professional intercultures, where their membership tends to be based on purely professional criteria (not birthright), they may adopt secondary positions with respect to cross-cultural communication (they tend not to initiate negotiations), and their institutions are often particularly transitory (based on contact-renewed networks rather than sovereign space). The application and exploration of these principles might ideally move Translation Studies toward the wider questions of Intercultural Studies.
\end{abstract}

\section{Introduction}

The accumulation and ordering of facts is a very necessary task; it gives us the data necessary for any empirical research, and indeed the archaeology at the basis of any history. If the facts are wrong, they should be corrected. Yet if the ethical task of Translation Studies is to ultimately improve relations between cultures, and the task of translation history is to make narrative sense of those same relations between cultures, we require more than just raw data about texts, dates, places, and names. We must also be able to portray active people in the picture, and some kind

\footnotetext{
* Anthony Pym

Intercultural Studies Group

Universitat Rovira i Virgili

Plaça Imperial Tàrraco, 1

43005 Tarragona, Spain

anthony.pym@urv.cat
}

Hermes - Journal of Language and Communication Studies no 42-2009 
of human interaction at work, particularly the kind of interaction that can string the isolated data into meaningful progressions. If all that is so, some principles of an evolving humanization, and debate about the same, are in order. Here we will sketch out two such principles.

But first, what might humanization involve in such a context? At the present state of play, we certainly cannot talk about humanization as a strict methodology or a series of precise objective concepts. The notion is certainly related to intellectual calls for a new humanism, to make the cold distanced analyses of postmodernism a little warmer and involving. In our own field, where deconstruction has had relatively little to say, is it perhaps easier to express discontent with the illusions of objective science that abound in systems-based Descriptive Translation Studies, particularly the kind of quantitative corpus work nowadays done on translations as texts. Our two principles will both embody something of that broad discontent.

However, simple opposition is not enough; nor is the simple call for the new. A humanizing project should add positive dimensions to the critique of scientific objectivity. In particular, it should create awareness of subjectivity in both its object and its approach. As Bourdieu (1980: 19-36) said of his sociology, we must "subjectivize the objective" (the things we study have been created by people and made available by people, always acting with specific purposes), just as we should "objectivize the subjective" (our own research responds to our own specific purposes, so we should take ourselves as an object of study as well). In that sense, humanization cannot be (or even seek to be) a strict method, perhaps an alternative objectivity, to be applied by all in order to ensure that the same results are reached by all. Any humanization is bound to be self-consciously inadequate in terms of intersubjective uniformity, or too caught up in its own dialectic evolution to stop and formulate any method beyond common sense. One might think here of Deborah Tannen's two-page "Toward a Humanistic Linguistics" (the afterword to Tannen 2007), which has remarkably little to say in itself and yet gains substantial content from the actual studies Tannen presents, notably through her insight into the way people create sense and involvement in conversation. All the adjective "humanistic" can really say there is: look at this, look what people are actually doing with language, look at how they make sense from repetition and prosody. That is theory in the sense of an invitation to look (the Greek theāhoran is 
also at the origin of "theatre"). For that matter, one might recall the way Derrida’s "grammatology" (1967), later called “deconstruction”, refused to present strict concepts because it was a practice, a way of reading texts, rather than a strict philosophy as such. It had a certain virtue as a constant call to action, despite the abstract analytical distance that fed into postmodern anti-humanism. Humanization could be something like that - a general way of proceeding, of discovering things about the world, of seeing what was hidden by a certain one-sided objectivity, rather than a formula for immediate and uniform application.

\section{Hispanic translation history as a field of operations}

This conscious inadequacy requires us to contextualize our principles with some care. Our particular frame here is the sub-field of Hispanic translation history. The principles themselves might hopefully be developed across the board, throughout the whole of Translation Studies, but they have evolved in a rather oppositional way within this special frame, mostly from our various case studies concerning the Hispanic past (Pym 1998, 2000).

That context is important because it also concerns the particularly national concerns of Hispanic translation history as studied in Spain, with its own traditions and values. This is a very special sub-field because, thanks largely to the values of Hispanic filologia as formed at least since the self-consciously foundational scholar and ideologue Marcelino Menéndez y Pelayo (1856-1912), it has accumulated a tremendous abundance of data, including data about human translators. In this tradition, the prime task of the filólogo is to locate and order the facts, and truth will come from the adequate ordering of those facts. There were certainly strong ideologies at work behind this simple empiricism, since Hispanic filologia took its frame from the Spanish language, derived from Latin in an apparently continuous Roman-Christian tradition. The filólogo could thus select data that would build a deceptively continuous past for the monocultural ideals of the present. That ideology did not really want to see the medieval confluence of religions (Islam, Judaism, Christianity) and of languages (Arabic, Hebrew, Latin, Romance) that others might consider the most vital and engaging part of Hispanic translation history. The accumulation of certain facts, for example in an anthology of literature (or translations) in Spanish, 
could thus edit out much of what we might term the interculturality of the Hispanic past. Between 1890 and 1916 Menéndez y Pelayo edited an intentionally monolingual and mostly monocultural 14-volume anthology of Spanish lyrical poets, "from the formation of the language to our days". Using a similarly national frame, we have two recent studies of "translation in Spain”, one by Ruiz Casanova (2000), the other by Lafarga/Pegenaute (2004) - the latter comprising no less than 872 pages -, that collect and present countless facts, as if data were somehow transparent to the world, and as if the limit "in Spain" were a wholly self-evident boundary.

Just as the history of poetry has no reason to concern one language alone, why should a history of translation concern one country alone? A restricted empiricism reproduces the ideologies of its frame.

At the same time, the collecting of facts, and the idea that truth can evolve directly from data, has incorporated a certain humanistic heroism. The same Menéndez y Pelayo also compiled a four-volume Biblioteca de traductores españoles (library of Spanish translators) (reprinted in 1952-53), many of whom did not fit in at all with the national tradition he was attempting to create. Some were Jews, Protestants, atheists, heretics or just foreigners living in Hispania. Indeed, quite a few of the translators also appear in his three-volume Historia de los heterodoxos españoles (history of Spanish dissenters) (1880-81), where the nationalist Catholic scholar affirms that faith has nothing to fear from shining light on all the facts, be they good or bad. There was at least one precedent to the task: Pellicer y Saforcada (1778) had produced a much smaller "library of Spanish translators", which necessarly included some of the Protestant translators that had produced their work in exile. And beyond that, we might recall the way the Holy Office (the Inquisition) kept copious records of suspected dissenters, just as the Spanish colonial administration documented the details of its own overseas iniquities. The keeping of data on people has a long and ambiguous tradition in this field. It may not be an entirely humanistic virtue that the Menéndez y Pelayo volumes were about people (poets, translators, dissenters), not just dates and places and texts. And the data on those people, like police files, concern both the monoculture to be created and its intercultural opponents, with an almost perversely passionate interest in the details of the latter. The policeman needs and occasionally admires the exploits of the criminal (and vice versa). 
The traditional accumulation of facts has continued in Hispanic translation studies. From the foundational work of Santoyo (1987, 1996, 1999) and the histories by Ruiz Casanova (2000) and Lafarga/Pegenaute (2004), more specific data on translators can be found in Cobos Castro (1998), Alvar/Lucía Megías (2001, 2003, 2004), Riera Palmero/ Riera Climent (2003), Medina (2007) and numerous articles in journals and proceedings. In many respects, this is a truly remarkable field for the study of translators, since in many areas the hard spadework has already been done. Indeed, so many raw facts have been gathered already, so many things are indeed known about translators, that talk of an empirical "humanization" will obviously not appear to be anything new. What could possibly be innovative in wanting to focus on translators as people? Below we will nevertheless describe why traditional Spanish filologia might possibly enter into conflict with our two principles.

There is a second major element informing our special context, and this is where the tension becomes more palpable. The impact of concepts from Descriptive Translation Studies (mainly from Toury 1995) has led to projects where data are not only presented, but they are presumed to form systems of a kind supposed to reveal a particularly quantitative truth. There are several influences converging here, from the state financing of research projects that look very scientific to the attraction of scientific-looking corpus linguistics, and indeed the scientific rigor of most kinds of linguistics within the Spanish context, not to mention the traditional filología of data collection. Whatever looks technical and methodical, whatever has lots of data and codes, has a positive value. Despite the tradition, human translators find remarkably little place in that world.

Telling here is the introduction to the Spanish translation (presented as the "edición española") of Toury's Descriptive Translation Studies and beyond (1995). The two editors/translators, Rosa Rabadán and Raquel Merino, present thirteen "basic concepts of Descriptive Translation Studies" (2004: 23-26) of which the technical majority (seven) are not even listed in the subject index of Toury's book, even though they are supposed to have been "extracted from Toury's work" (Merino 2005: 3 n1). The added terms are (if we may translate from Spanish): "inventory-catalogue", "regularity" (elsewhere glossed as "norm"), "corpus", "text pairs", "comparison", "native text” and "derived text”. This should give a fair idea of the way things are going: this empirical 
methodology is basically designed to form extensive corpora, compare texts, and look for regularities. We have elsewhere criticized Toury for abstracting too quickly from human translators (Pym 1998: 108), and we would generally argue that system-based studies are dehumanizing by nature, but this Spanish introduction goes even further than Toury, presenting descriptive translation research as being explicitly bottomup and based on data held in corpora.

Not by chance, the translators of Toury's book have been the main figures behind a major research project in Spain on translation and censorship, known as the TRACE project (see for example Merino/Rabadán 2002). That project has some of the most fascinating and engaging data to be found in any investigation into translation anywhere, including some surprising and occasionally surrealist censors' reports on foreign films and plays in Franco's Spain. As Merino claims (2005: 13), "TRACE's catalogues have no doubt gathered more information on what got translated, and how, by whom..., than any other to date." True enough: this is a further example of the tremendous Hispanic capacity to accumulate and order data. The findings, however, never really rise above the level of data. We certainly discover many things that we did not know were there (for example, numerous pseudotranslations and repressed translations, and many loopholes in the later years of the Franco dictatorship), and we certainly have nothing against the use of corpora and quantitative methods (they constitute three chapters of our Method in Translation History of 1998). However, mere descriptive organization cannot explain why such things are there, nor why they needed to be discovered. Although Merino's papers on homosexuality on the Spanish stage in the late Franco years (cf. Merino 2005, 2007) present much revelatory and genuinely exciting material, after years of methodical investigation the researcher's only real conclusions are selfdescribed as "fundamentally methodological" (2007: 259). This results in numerous notes like the following:

The text signed by Artime and Azpilicueta for report 533/74, which we shall call TTce2, may be compared with ST, and with TTce1 (or TTce1.1,TTce1.2...), in order to establish the text chain that led to TTce2 (or TTce2.1, TTce2.2...). (Merino 2007: 255-265) 
For stylistic reasons alone, some humanization is needed. Not all the presentations are so technical, of course. In one conclusion we find something a little more revealing:

\begin{abstract}
... now that we have compared all the texts with each other and we have established the comparable pairs, the results indicate progressive textual modification [manipulación], a constant negotiation, with the text in the centre. A text that the censors confronted (the total number of modifications proposed by the censorship apparatus is surprisingly low in this case), and a text with which the petitioners [those presenting the text for approval] sought to force institutional resistance in a period of political involution, which contrasted visibly with a relentless social eclosion. (Merino 2007: 260, our translation)
\end{abstract}

This is a conclusion. The passage is by no means wrong or misleading (despite the missing predication in the second sentence): text modifications can indeed be seen as negotiations, and the late Franco regime can of course be seen in terms of tension between inward and outward movements. Note, however, that most of the active verbs in this conclusion are enacted by texts, and the analyzed relations remain on the level of texts. Indeed, in the study, the actual social actors (the "censors" and the "petitioners") only really appear as a series of codified text modifications. When analysis remains on that level, we are really no closer to understanding why certain translations are the way they are, we have tremendous difficulty relating the textual to the social ("involution" and "eclosion" are merely assumed here, without analysis), and we are certainly a long way from understanding the ethical issues involved in the imposition of a centralized Catholic state morality. Quite different conclusions might have resulted from a few case studies on who the censors were, who the translators and intermediaries were, and what social networks (extending in many cases beyond the national system of texts) brought the two sides to the metaphorical negotiation table. Such case studies might reveal how many Spaniards were living and communicating outside Spain; how many mediators suffered from self-censorship; how much the repression and suppression of homosexuality not only twisted language through the censor (in both the social and psychoanalytical senses), not only blossomed into entertaining innuendos and half-understandings, but also led to tortured lives, lived lies, sham marriages, habitual fear of pain and persecution, so many systemic perversions. Failing any of those human dimensions, in the absence of even a 
hint of humanistic ethical concern, the actual ideological message coming from catalogue annotations and abstract two-force systematic studies, if any, is perhaps that “the Franco regime wasn't really all that bad”. There are indeed loopholes in any totalitarian system, and that is indeed a very good lesson to teach, but none of this seems reason enough for turning methodology into an apologetics.

Our institutional context is thus framed by two movements: traditional filología, and a particularly scientistic mode of Descriptive Translation Studies. The former produces much data on translators; the latter is more interested in data on texts; both see progress in terms of accumulating even more data. Both movements, however, lead to an intellectual impasse on questions of causation and the dynamics of cross-cultural relations. Both might be characterized in much the same terms: full of raw data, and relatively unrelieved by original ideas.

To go beyond that impasse, one might turn to the growing interest in possible sociologies of translation (cf. Pym et al. (eds.) 2006; Wolf/ Fukari (eds.) 2007; Buzelin/Foloran (eds.) 2007), all of which could be humanizing in a way. Sociology, however, perhaps does not always have all the answers. Its classical maximum category is the "society", the "social system", and that may be as inadequate to the study of crosscultural communication as are the systemic abstractions that have been with us since Russian Formalism. For example, Bourdieu (1999) would seek to understand literary translations only within the field of publishing in France, instinctively reproducing the same kind of national frame that we find in studies of Hispanic translations. In the case of Bourdieu, the very definition of the field, and the subsequent selection of subjects, results in a markedly anti-American cultural elitism. The methodologies of systems are not ideologically neutral, and sociology will not provide any immediate panacea for the problems of Translation Studies.

In lieu of grand solutions, we thus propose two simple principles.

\section{First Principle: Study translators, then texts}

Instinctively, scholars of language or literature reach for a text, to check its language, to compare it with a source or, more profitably, to compare translations with alternative translations. It is a normal thing to do. However, as soon as we do this normal thing, we find ourselves dealing with an issue of sides: target and source, here and there, home and 
away, even when one of the sides is only virtual (as might occur when comparing various translations of the one source). We are thus methodologically invited never to question the line separating those two sides, nor the correlated belonging of whatever should be on either side. Let us apply this view to twelfth-century Hispania (Spain did not yet exist): on one side everything seems to be in Arabic, with Arabic syntax, Arabic mentality, and all the stereotypes habitually attached to such things; on the other we find the same but in late medieval Latin. We are thus invited not to see the amount of Arabic that is in things Latin, nor vice versa, nor the extent to which our epistemological borders conceal the middle grounds. This is a problem of all the methodologies that assume a simple border between two sides, especially the most systemic of them, precisely because of the methodological way in which system studies assumes borders.

The two-sided models flounder rather badly when we enter something like the Hispanic twelfth century, commonly and erroneously glossed as the Toledo School. There, one side is perhaps Arabic and Islamic and respectably other, 'our' side is Latin and Christian and deceptively familiar, but in the overlaps we find translating Jews (whose families had moved across from Islamic society), Mozarabs (Christians who had lived within Islamic society), the occasional Morisco (Muslims living in Christian society), not to mention the oral use of Romance, or some kind of Castilian, or Leonese, or Aragonese, or Majorcan, or Catalan, or indeed written Hebrew texts, and many mixes of all those things. All those languages and modes of thought, including the Islamic, might legitimately claim to be Hispanic, all within the one geopolitical complex. In such cases, the basic binary divisions are of remarkably little help. The mixes of peoples destroy the clear lines of methodology.

A facile way to deal with such problems is to manifest them, to describe the ways all language products, including translations, escape homogeneity and create difference. One can draw up the lists of data. But then the immediate problem is how to make sense of the data without imposing precisely the borders that constitute the problem. A more radical step is to question whether our object of study need be a language product at all. If the here-or-there border is a function of texts as translations, the overcoming of that border could involve looking at something else. Translators, the human producers of translations, might 
also be legitimate objects of knowledge. The history of translators is at least as valid an organizing principle as have been the various focuses on source-text authors, source texts, or target-vs.-source languages, cultures or nations.

Once you start to look at translators rather than translations, several things can be done. Let us list a few.

\subsection{Unearth the obscure}

First, you discover that it is rarely easy to find out about translators as people, with their own life stories and evolving ideologies. In the Hispanic field the situation is certainly not as bad as elsewhere: as we have indicated above, there is a remarkable abundance of raw data. However, the long lists tend to be limited to bibliographical titles, dates of birth and the occasional geographical reference. Apart from that, the cases most fleshed out tend to be translators who found fame wearing a different hat, as authors, political figures, polemicists, and so on. Considerable archival work is often required to piece together the elements of a biography; far more is needed before something like a character can emerge. When the searches are possible, what they reveal is not only a hidden labyrinth of textual history but also, indirectly, a few of the historical reasons for the longstanding suppression of translators as significant cultural figures.

For example, someone called Fernando Maristany was a fairly obscure Catalan translator of poetry, responsible for some eight anthologies of translated verse in Spanish between 1914 and 1921. His contribution to Spanish literature is quantitatively impressive, yet few literary histories bear any mention of him. Finding out about his life is rather like uncovering a forgotten tomb (cf. Pym 1995). Why should this be so? The reasons for Maristany's marginal status must include the rupture of the Civil War and perhaps his cultural position as a Catalan in Spanish letters. Yet we cannot pretend there has been some kind of canonical conspiracy against him because of his status as a translator. It is not generally useful to set out to right a major wrong in the name of oppressed intermediaries. Although there may be great human qualities to be revealed through translation history, Maristany, along with many of his ilk, was wilfully marginal, casting himself into a service role, adopting grossly conservative or derivative stances on most issues, and 
producing some occasionally ghastly verse. Uncovering and admitting such things is part of the fun of the game. Since these people are mostly not seen by the more systemic views, they can tell us something about what systems leave out, and why.

\subsection{Follow the multidiscursive}

Even when less than heroic, the translators of the past tend to force recognition of what we might call multidiscursive mediation. This means that they participate in more than one professional discourse (where we use the term 'discourse' to refer to a way of communicating that is typical of a certain kind of habitual interaction and is not bound to a language system; see Pym 1991). Maristany, for example, was an editor, publisher and author in his own right, as well as a translator. His many texts, which include prefaces, catalogues and correspondence, weave in and out of all those professional discourses. Many other intermediaries use translation as just one leg of a multifarious career, perhaps in initial attempts to enter the literary world, in the leisurely creativity of retirement, or, particularly in Hispanic history, as a means of survival in years of hardship or exile.

The resulting connections and overlaps between the various discourses of cultural mediation can be of great methodological use. To appreciate why, consider for a moment the directives of a method that would have us look at translations first, then the receiving (poly)systems second (a principle enshrined in Toury 1995, especially as understood in the "edición española”). Such a method obliges us to move from the several thousand shifts embodied in a translated fragment (wherein many a descriptive scholar already becomes lost) and confront the whole churning dynamic of a culture in search of some kind of explanation for the translation. Where should the researcher start? One could remain on the level of method and data, as we have seen, or one could jump straight to abstract systemic generalizations such as norms and laws, or canons and genres, or centres and peripheries. But there are ways of bridging those two levels, and those ways concern human translators.

To get a handle on the systems, at least, it is eminently useful to consider the discourses the translators brought together, to try to see the way those discourses configured intercultural space, and then to look at the main debates in which those discourses were used. Where should 
one start? Probably from a few intermediaries arguing about their task, then see where that leads, regardless of any presupposed corpus, catalogue or system.

If we are in the twelfth century, tension and disagreement can be seen behind official admonitions about translation and teaching practices, which indicate the existence and apparent collusion of the mediating practices they outlaw. Many translators appear to have been teaching as well. That overlap leads quickly to the church and the monastic orders, who were supposed to be organizing and paying for teaching practices: most of the translators were working for them, yet spreading the knowledge of pagan science. In our own research, that kind of questioning eventually focused on the Order of Cluny, which financed translations from Arabic, starting with the first Latin Qur'an from 1142. Who were the people in this order? Where did they come from? What did they want the translations for? Why did they have the translation done in Hispania? Some answers to those questions are proposed in our study (Pym 2000) and have little place here. Suffice to note that our search for answers about translators in twelfth-century Hispania led us to start our narrative in tenth-century Helvetia, actually in 972, when the abbot of Cluny was captured by Arabs in the Alps as he was returning from Burgundy to Rome. Yes, there were Hispanic Moors in the Alps of Europe; yes, the interculturality of Hispania can be told from there; yes, a history of translators can start from an event that is not a translation (we were looking for where the gold came from, and why a Clunaic would use military metaphors for a translation from Arabic). Needless to say, that kind of narrative starting point and procedure upsets those who believe in national systems of complete data. In his review, Santoyo (2002) sounds relatively scandalized that our history should not even mention what might be the first written translation done on Hispanic lands (the territory of Spain should be the frame?), and others might be upset that we do not herald the first into the Spanish language (the target language should be the underlying system?). It is not surprising that a traditional filólogo would try to read our history as an archaeology of nationally ordered data, and would be disappointed not to find it. Our translators led us elsewhere.

Our heterodoxy can be taken further. In the thirteenth century, similar multidiscursivity led us to consider the role of the Jews under Alfonso $\mathrm{X}$, in the context of implicit debates about the role of service mi- 
norities in a fledgling national system. In the fourteenth century, there were interesting things happening around the mediating positions of Catalan and Aragonese, with underground problematics that have survived through to the autonomías of Spain today. And so on. In each case, questions about translators lead to different configurations of discourses, and to different tensions and negotiations across social and cultural divides.

The debates and mixes between discourses often give indications about what orthodoxies were being challenged, and about the ways in which new norms were being fought over. Humanization has never been a question of looking at people just because they happen to be there, nor about compiling police files, nor about counting the heads in a sociological survey. It has far more to do with searching for the multiple causes that give intermediaries various freedoms to choose.

\subsection{Accept multiple allegiance}

Once we see translators as mediators generally in several domains, it becomes quite normal to question their cultural allegiance to any one side. Were the protoscientific translators of twelfth-century Hispania entirely on the side of Christian doctrine? One suspects not. Were the Jewish translators paid by Alfonso the Learned in the thirteenth century solely interested in the well-being of their king? Probably only to the extent that they were also physicians. Américo Castro (1948: 454478) notes that the Jewish translators worked into Castilian whereas the previous written translations had mostly been into Latin, and he suggests that this was intended to undermine the Latin of Christendom. Whether or not we regard this as an unfounded conspiracy theory, we can only deal with such arguments, for or against, once we abandon the preconception that mediators work - or should work - for one side only. Toury (1995: 12) methodologically postulates that translators "operate first and foremost in the interest of the culture into which they are translating", but he presents little evidence to back the principle up. It seems equally as likely that intercultural professionals also work for themselves, for their own material well-being, and perhaps even for some ideals that will outlive the decline of national sovereignties. In our study of the twelfth-century translators, we had to allow that allegiance 
to empirical science was sometimes a more powerful calling than the gold, or indeed than anything Islamic or Christian.

\subsection{Trace the movements}

Find the translators, see who paid them, see what discourses they worked with and mixed, what minor elements of power they thus found. As a rule of thumb, the more technical the knowledge involved, the less it is subject to social control mechanisms, and the more power intermediaries have over their decisions. Usually, unsurprisingly, this relative independence leads to considerable mobility. Mediators with specialized competencies tend to move, not only from discourse to discourse, not just from client to client, but also from country to country. That mobility no doubt increases with the development of transportation systems, yet the phenomenon is by no means new. Consider the case of the Englishman Robertus Ketenensis (many other names are possible), mostly responsible for the first Latin version of the Qur'an (the one financed by Cluny from 1142). He did the job 'in the region of the Ebro', therefore in Spain, but received payment and instructions from an abbot based in Burgundy. So was he an ideological foot-soldier of Christendom? Perhaps, since immediately after the translation he was appointed archdeacon at Pamplona, maybe as a reward. But he could not have stayed there long. Robertus signed a translation in Segovia in 1145 and drew up astronomical tables for London in 1149. Vocational integration into the church structure was obviously not his personal aim. His mobility reveals his allegiance, to science more than to church or state structures, and that kind of loyalty promotes mobility. You go where the opportunities are greatest. We can thus trace the histories of moving feet, and the paths they indicate make a mockery of nationally based systems.

\subsection{Some objections to this principle}

So much for what we might discover by looking at translators first. Good scholars will object here that our distinction is naïve, that it somehow suggests the immediate availability of people long dead, that such facile humanization eclipses alterity, that we have succumbed to an essentialism of presence, that what we are really working on is always a series of texts, be they translations or biographical documents, and those texts all have to be interpreted with philological care. Yes, of 
course our historical translators are products of language - that is why we are talking about discourses. Yes, of course the historian actively constructs the subjectivities that populate historiography - that is why we are talking about the asking of questions. So what could possibly be new in humanization?

There is a difference involved, a very fundamental difference, when we go beyond the narrow focus on language in texts. On the one hand, a certain set of research questions focuses on reconstructing social profiles, financial transactions, dates and movements, the archaeological details that might piece together a social situation rather than just assume a whole system. These would be applications of network analysis, and they are to be applauded. On the other, we find attempts to privilege translators as a 'voice' within translations, and to leave it at that (see for example Hermans 1996: 23-48, and Hermans 1998: 135-142). Such attempts make for interesting reading performances, destined to find results. However, the questions they are asking, like the methods they employ, seem to reveal something hidden (translatorial subjectivity is indeed often suppressed) that remains quite obvious in the extra-translational discourses of historical translators. There seems little reason why translation history should deploy intricate textual criticism when it could attain many of its goals more directly by asking biographical and sociological questions, or looking critically at the language in prefaces, correspondence and the subject's texts other than translations. That is, by seeking its points of departure in translators rather than in translations.

\section{Second Principle: Look for professional intercultures}

We have mentioned 'intercultural space' and 'intercultural professionals' without properly explaining what the terms mean. For us, that 'inter-' is not to be confused with things moving from one culture to another ('cross-cultural' seems an adequate adjective for that), nor with heterogeneity within a social space ('multicultural' would suffice there). Instead, it implies an overlap or intersection like the following: 


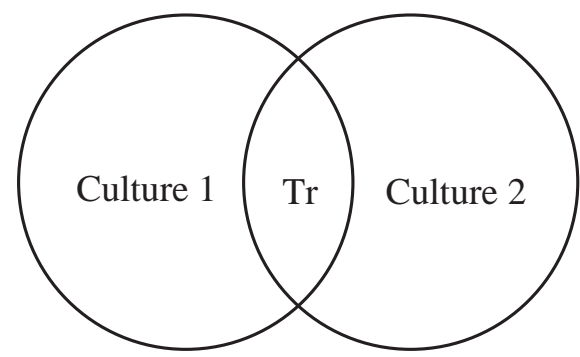

Figure 1. The simplest model of an interculture $(\operatorname{Tr}=$ hypothetical position of the translator)

Here we see two cultures (there could be more) intersecting each other, with a symbolic translator $(\mathrm{Tr})$ placed in the intersection. That is a very simple model; it is not a law of translation; it is not a definition of all translators; it does not assume there are only two cultures in play; it does not suggest that cultures are homogeneous circles (a more complex model would map the networks, as in Pym 2007). The simplification might nevertheless be useful in that it implicitly challenges axiomatic beliefs in fidelity to the source (as if all translators were agents of Culture 1) or loyalty to the target (as if they were all wholly determined by the systems of Culture 2). The model thus questions both fidelity-based evaluations and target-based systemic approaches. It suggests that translators can work in a fairly specific locale, drawing on more than one culture (they have at least learnt something of another language) but wholly determined by none.

In the Hispanic context, this kind of intersection can most obviously be seen in the position of the translating Jews and Mozarabs in the late middle ages. Many Jewish families moved from Islamic to Christian territories, thus uniting competencies in Arabic and Romance, as well as Hebrew. The Mozarabs were Spanish Christians who had lived within Muslim Arabic-speaking society, and were thus similarly able to bring together different language skills. It seems there was a large community of them in Toledo, where their property contracts were bilingual documents, in Arabic and Romance. These communities may have produced translators able to participate in professional intercultural groups. However, the teams of translators and revisers also included, in differ- 
ent ways on different occasions, Church Latinists and various travelling scholars from many parts of Europe. So there can be no direct read-off from the multilingual societies and the existence of intersections for translators. Things are usually more complex than the simple circles.

Since we find no direct correspondence between societies and translators, we must distinguish between, on the one hand, the general interculturality found in social structures, and on the other, the kind of professional interculture that configures the way people come together to work on cross-cultural communication. Bilingual and multilingual communities are certainly intercultural, but the object of our own studies is more specifically the professional intercultures that only sometimes draw their members from such communities.

When we talk of professional intercultures, we are thus going quite a few steps further than the general observation that most social borders are porous. The non-abstractive substantive ('interculture') should suggest that the middle space has structures and dynamics that are something like those of cultures themselves. Rather than a wholly accidental feature of history, this overlap would function as a cultural space with its own membership rites, norms of behaviour, ideologies and ethics. Do we have any real grounds for proposing such a model?

This requires us to formulate some of the ways in which a professional interculture might be different from more general interculturality. Here is a shortlist derived from our case studies in the Hispanic domain.

\subsection{Ask about provenance}

As we have argued, in the Hispanic field the notion of a professional interculture cannot be construed to refer to a particular ethnic group. There is certainly no pueblo or Volk whose members are exclusively translators. There is no question of membership by birthright, although birthright-based mediatory groups can be found in West Africa, in the Sparta of Herodotus, and in the Oranda Ts $\hat{j} j i$ interpreting in eighteenthcentury Japan, at least.

In our field, mediators tend to come together because of their professional skills, and in many cases precisely because they come from quite different social and cultural backgrounds. In the twelfth-century translation teams (to continue with our main example) we find Jews 
and Mozarabs, who brought competence in Arabic, working alongside clerics from various parts of Europe, who brought competence in Latin, with some kind of spoken Romance presumably being used between the two groups in the actual translation process. That is, the interculture is formed precisely on the basis of the diverse provenance of its members. Much the same logic can be seen in the localization teams of today, where different language and technical skills are required of each member. Membership of a professional interculture may thus be determined according to combinations of competencies and skills more than by any form of primary belonging (birthright, race, ethnicity, mother tongue).

It would nevertheless be factitious to assume that translators work together simply because they translate. We have already allowed that translators usually do more than translate; their multidiscursive status could only contradict any membership exclusive to translators. We fare rather better when looking for relationships between what we might call mediating professions, covering all the various forms of cross-cultural communication. An interculture might thus include diplomats, clerics, missionaries, literary critics, foreign-language teachers, journalists, cross-cultural negotiators at all levels. In each case, we must be prepared to follow the links that lead to such configurations, even at the risk of producing something more than translation history ("intercultural history" is a name awaiting content).

At the same time, there should be no suggestion that competencies and skills somehow make all members of an interculture equal. The translation teams of the twelfth and thirteenth centuries were not necessarily happy families, and primary provenance might have something to do with the tensions. For instance, there can be little doubt that there were hierarchical relationships between the Latinist clerics and Arabspeaking Jews and Mozarabs, since the former were on the side of the ecclesiastic or state client, and the latter were not always in control of the written word (in the thirteenth century, King Alfonso the Learned claimed he edited the translations, with no knowledge of Arabic). Today we might find similar tensions in localization teams, notably between translators and project managers, with reviewers and language consultants standing somewhere in between. Indeed, the hierarchies may become so pronounced that the separate professional identity of translators is enhanced, as they band together because of their collectively dis- 
advantaged position within the interculture. That identity would then become a function of the interculture.

\subsection{Analyze secondariness}

The discovery of professional intercultures of this kind might not be possible if we start from Toury's more restricted interest in translators, methodologically limited "to the extent that they are members of a target culture, or tentatively assume that role" (1995: 172). That is the principle by which there would be no overlaps; the real actors remain the cultures, or systems, or polysystems. For us, there is no one-to-one read-off between what translators do and what their source of target cultures are like. After all, if there were such a correspondence, we would only need to look straight at the systemic variables, overlooking individual human agency.

At the same time, we cannot claim there is complete autonomy from social contexts. We have just admitted that hierarchies within the professional interculture may depend on factors of provenance. Indeed, viewed in terms of where their economic capital necessarily comes from, intercultures would always need the support of more primary social structures. They would thus logically tend to present themselves as being in some way in relation to, but also secondary to, the relations upon which they operate.

For example, in the years between 1430 and 1437 there was a famous debate about translation between the Spanish bishop Alonso de Cartagena and the Italian Renaissance scholar and statesman Leonardo Bruni. The encounter can be seen as marking the watershed between scholastic and humanist translation theories. In that debate, Cartagena was not so much representing Spain or acting as a Spaniard as he was defending a certain tradition for the translation of Aristotle. The debate was situated in a meta position, second to the more primary division of cultures. Cartagena and Bruni could thus retain their primary cultural identities while at the same time finding much common ground as translators and scholars. Both were concerned with the use of classical texts to better their respective societies (they differed on the means, not the end). Further, within their respective economic systems, both had contacts in the wool trade that connected Burgos and Florence, so they had complementary financial interests in maintaining good relations (see 
Round 1993: 72). They could both remain functional members of their respective social systems and participate in a European interculture.

There is no need to pretend that social systems have suddenly disappeared.

\subsection{Accept discontinuity}

In our studies, professional intercultures seem to be particularly transitory. People with different skills and competencies come together to work on cross-cultural relations in a given sphere of human affairs; they do their work; they mediate; then their professional relations loosen as the historical task diminishes. This might account for a certain lack of historical awareness in translation practice; few intermediaries would claim to have a history as a social group. It might also explain why Julio-César Santoyo, in introducing his anthology of Hispanic translation theories, observes that the various fragments "do not constitute a 'tradition', nor do they depend on each other genetically” (1987: 19, our translation). Traditions in translation theory might be the exception rather than the rule; the fundamental problems are perhaps never resolved, they merely lose importance for a while. They come and go, with the intercultures themselves.

In Hispanic history, the basic principle that translators work within professional intercultures extends well beyond the medieval teams. The same principle might help organize the various Protestant and protesting translators forced to leave the Spain of the Counter-Reformation and enter the Spain of European exile. It might also be found in the Sephardic and Morisco diasporas, in the tradition of cultural mixes and renegade churchmen in the Americas and Philippines, in the waves of intellectuals expelled as Jesuits, afrancesados, Liberals and Republicans, to name but a few historical cases. Hispanic interculturality has a rich past in the medieval mixes, and a tragic modernity in the many cultural groups expelled by the rising monoculture. Translators can be found in those mixes, along those fringes, in those exiles, because of the social interculturality they were born into or had imposed upon them by forced displacement. But there is certainly no historical awareness connecting those situations. For example, the exiled Spanish Protestants translating the Bible in the sixteenth century expressed no particular identification with the position of Hispanic Jewish translators in previ- 
ous centuries (although they probably borrowed from Jewish translators of the Bible into Castilian), nor with the position of northern European translators in medieval Hispania (who linked with the cultural networks of the Jews). We might argue that the translators should have thought about such connections. However, the weight of primary cultural identification, added to the historical nature of their various ideological callings, means we cannot really expect translators to act in term of century-spanning professional intercultures.

Deprived of great diachronic capital, intercultures would thus appear to wax and wane in accordance with circumstance. A certain kind of historiography might nevertheless trace some long lines joining up the intercultural dots. For Columbus, translation was a problem solved by taking along a polyglot Jew and, failing that, capturing natives. From that humble beginning grew the wide intercultures promoted by church and state in the Americas (Cisneros argued for the development of a native-born control caste), historically mediating until that middle overlap grew so wide as to become a new Spanish-speaking culture in itself, known as Spanish America. And more or less parallel to that growth of a culture from a professional interculture, the caste mediating from Latin declined in historical importance and power, becoming a thin intersection surviving as good conscience or taste in our churches and universities today. Intercultures may disappear either by becoming general or by shrinking away. The kinds of narratives they allow, the stories of how cultures develop and decline, remain of interest even despite the lack of historical consciousness among the actors.

\subsection{Follow cross-cultural networking}

No matter how much we might want to describe the continuity of something like Hispanic culture, significant synchronic networks are frequently formed between translators in ways that constantly cross cultural borders. We might think again here of the translation teams of Hispania in the twelfth and thirteenth centuries, where Jews and Mozarabs were often the mediators between Islamic and Christian cultures, or of the European Protestants moving between the centres like Wittenberg, Leuven, and London in the sixteenth century, or indeed of the many foreigners brought together in the translation schools and agencies of Spain today. 
Now, where were the intercultures physically located? The question can be rephrased: Where were the networks between professions most intense? Where did people of different cultural backgrounds come together? The answer, usually, is to be found in urban centres, particularly big cities, the hubs of cross-cultural communications. Translators tend to be either in cities or in the networks centred on cities. Electronic space might be expected to change such concentrations, yet the age of globalization has at the same time brought about the world cities specializing in complex communications. Is it then really productive to ask if translators belong to one culture or another? Was Maristany Spanish or Catalan? Was Cartagena Castilian, Converso or part of the European church? If we think in terms of cities and networks, such questions become rather meaningless. The places of intercultural belonging are not the rural expanses and seas of nation-states.

\section{A plan for the future}

Translation Studies has witnessed quite a number of proclaimed returns to the future, from the "cultural turn" announced by Lefevere/Bassnett (1990: 8), the "social turn" heralded by Wolf (2006), with a forlorn "return to ethics" along the way (Pym 2001) and, more recently, a hypothetical "linguistic re-turn" (Vandeweghe et al. 2007) to square the circle. Like so many girl-guides, we pretend that our hopes and visions lead the way. A little history, however, should suggest that cultural and social concerns were written into system models from the Russian Formalists onwards, and that traditional discourses on the ethics and linguistics of translation have remained fairly constant all the way through. In this context, no call for humanization can be seen as a movement that challenges the entire past or is in any way automatically in course. As should be clear from the above, our two simple principles would broadly oppose the implicit anti-humanism of system-based studies, of what was once called formalism but would also include much of current corpus-based linguistics, just as it opposes the overt anti-humanism of much text-based deconstruction. On the other hand, it would embrace approaches that see translators operating with ethical concerns in cultural contexts, which may or may not meet up with the many sociological concepts now on offer (for a survey, see Pym 2006). 
In no case, however, should humanization be seen as a strict methodology. At best, it is a mode of asking questions that may lead to unforeseen answers. One might nevertheless hope, of course, that the questions can help subvert the whole of Translation Studies. Here is the plan:

1. Instead of the binarisms of source vs. target, language vs. language, culture vs. culture, a focus on translators should make us think about something operating across the two sides, in their overlaps, in the spaces of what we have tried to think of as professional intercultures.

2. A focus on individual translators should also, through its own specific weight, lead researchers to model intercultural decision-making as an ethical activity, a question of actively choosing between alternatives, rather than mere compliance to rules, norms or laws.

3. Once you reach the discussion of ethics in intercultures, the focus on translators should ideally stir up a concern with causation, with the reasons why some decisions are taken rather than others, or why some ethically laudable or reprehensible effects ensue.

4. The study of individual translators also tends to show that they often do more than just translate - they engage in many aspects of cross-cultural communication. Research based on them might thus be expected to evolve into something like Intercultural Studies, or into a form of Translation Studies where the term "translation" is taken in a very wide sense. This is already happening within Postcolonial Studies and Cultural Studies, where postmodern humanity is increasingly portrayed as translational. It would be a pity if that development were to leave behind those members of our societies who are actually called translators.

5. The focus on translators should simultaneously raise wider questions about subjectivity and communication. If we can ask where translators are culturally located and why they communicate in one way rather than another, precisely the same question can be asked about ourselves. In short, the focus on translators should help raise the fundamental issues of action research.

To tell all, we would like Translation Studies to blend into Intercultural Studies. Hence the interest in humanization. 


\section{Bibliographical references}

Alvar, Carlos/Lucía Megías, José M. 2001: Una veintena de traductores del siglo XV. Prolegoménos In T. Martínez Romero et al. (eds.), Essays on Medieval Translation in the Iberian Peninsula. Castelló: Universitat Jaume I/Omaha: Creighton University, 13-44.

Alvar, Carlos/Lucía Megías, José M. 2003: Repertorio de traductores del siglo XV: Tercera veintena. In Quaderns de Filología. Estudis Literaris 8, 1-40.

Alvar, Carlos/Lucía Megías, José M. 2004: Repertorio de traductores del siglo XV: Segunda veintena. In Literatura y transgresion: En homenaje al profesor Manuel Ferrer. Amsterdam: Rodopi, 89-113.

Bourdieu, Pierre 1980: Questions de sociologie. Paris: Minuit.

Bourdieu, Pierre 1999: Une revolution conservatrice dans l'édition. In Actes de la recherche en sciences sociales 126-127, 3-28.

Buzelin, Hélène/Folaron, Deborah (eds.) 2007: Special issue on "Translation and Network Theories”. In Meta 52/4.

Castro, Américo 1948: España en su historia. Cristianos, moros y judíos. Buenos Aires: Losada.

Cobos Castro, Esperanza 1998: Traductores al castellano de obras dramáticas francesas (1830-1930). Córdoba: Universidad de Córdoba.

Derrida, Jacques 1967: De la grammatologie. Paris: Minuit.

Hermans, Theo 1996: The Translator’s Voice in Translated Narrative. In Target 8, 23 48.

Hermans, Theo 1998: Some Concluding Comments on the Debates and Responses. In Current Issues in Language and Society 5, 135-142.

Lafarga, Francisco/Pegenaute, Luis (eds.) 2004: Historia de la traducción en España. Salamanca: Ambos Mundos.

Lefevere, André/Bassnett, Susan 1990: Introduction: Proust’s Grandmother and the Thousand and One Nights: The 'Cultural Turn' in Translation Studies. In Susan Bassnett/Lefevere, André (eds.), Translation, History and Culture. London and New York: Pinter, 1-13.

Medina, José Toribio 2007: Biblioteca chilena de traductores (1820-1924). Segunda edición. Santiago de Chile: Centro de Investigaciones Diego Barros Arana.

Menéndez y Pelayo, Marcelino 1880-81: Historia de los heterodoxos españoles. 3 vols. Madrid: Librería Católica de San José.

Menéndez y Pelayo, Marcelino, ed. 1890-1916: Antología de poetas líricos castellanos desde la formación del idioma hasta nuestros días. 14 volumes. Madrid: Viuda de Hernai.

Menéndez y Pelayo, Marcelino 1952-53: Biblioteca de traductores españoles. Vols. 54-57 of Obras completas. Santander: Consejo Superior de Investigaciones Científicas. 
Merino Álvarez, Raquel/Rabadán, Rosa 2002: Censored Translations in Franco’s Spain: The TRACE Project - Theatre and Fiction (English-Spanish). In TTR: traduction, terminologie, rédaction 15/2, 125-152.

Merino Álvarez, Raquel 2005: From catalogue to corpus in Descriptive Translation Studies. Translations Censored under Franco. The TRACE Project. In Revista Canaria de Estudios Ingleses 51, 85-104. Available at [online] http://www.ehu.es/ trace/publicaciones/2005aRMA_RCEI.pdf.

Merino Álvarez, Raquel 2007: La homosexualidad censurada: estudio sobre corpus de teatro TRACEti inglés-español (desde 1960). In Merino Álvarez, Raquel (ed.), Traducción y censura en España (1939-1985). Estudios sobre corpus TRACE: cine, narrativa, teatro. Vitoria: Servicio Editorial de la Universidad del País Vasco, 243286. Available at [online] http://www.ehu.es/servicios/se_az/trace.pdf.

Pellicer y Saforcada, Juan Antonio 1778: Ensayo de una bibliotheca de traductores españoles. donde se da noticia de las traducciones que hay en castellano de la Sagrada Escritura, santos padres, filósofos, historiadores, médicos, oradores, poetas, así griegos como latinos; $y$ de otros autores que han florecido antes de la invención de la imprenta. Madrid: Antonio de Sancha.

Pym, Anthony 1991: Limits and Frustrations of Discourse Analysis in Translation Theory. In Fremdsprachen 2-3, 29-35. Revised version in Revista de Filología de la Universidad de La Laguna 11, 1992, 227-239. [online] http://www.tinet.org/ apym/ on-line/translation/discourse.html.

Pym, Anthony 1995: Translational and Non-Translational Regimes Informing Poetry Anthologies. Lessons on Authorship from Fernando Maristany and Enrique DíezCanedo. In Kittel, Harald (ed.) 1995, International Anthologies of Literature in Translation. Berlin: Erich Schmidt, 251-270.

Pym, Anthony 1998: Method in Translation History. Manchester: St Jerome.

Pym, Anthony 2000: Negotiating the Frontier. Translators and Intercultures in Hispanic History. Manchester: St Jerome.

Pym, Anthony (ed.) 2001: The Return to Ethics in Translation Studies. In Pym, Anthony (ed.), The Return to Ethics. Special issue of The Translator. Manchester: St Jerome Publishing, 50-59.

Pym, Anthony 2006: On the social and the cultural in Translation Studies. In Pym, Anthony/Shlesinger, Miriam/Jettmarová, Zuzana (eds.), Sociocultural Aspects of Translating and Interpreting. Amsterdam/Philadelphia: Benjamins, 1-25.

Pym, Anthony 2007: Cross-Cultural Networking: Translators in the French-German network of petites revues at the end of the nineteenth century. In Buzelin, Hélène/ Folaron, Deborah (eds.), Special issue on Translation and Network Theories. Meta 52/4, 744-762.

Pym, Anthony/Shlesinger, Miriam/Jettmarová, Zuzana (eds.) 2006: Sociocultural Aspects of Translating and Interpreting. Amsterdam/Philadelphia: Benjamins. 
Rabadán, Rosa/Merino, Raquel (eds. \& trans.) 2004: Gideon Toury: Los Estudios Descriptivos de Traducción y más allá. Metodología de la investigación en Estudios de Traducción. Madrid: Cátedra.

Riera Palmero, Juan Bautista/Riera Climent, Luís 2003: La ciencia extranjera en la España ilustrada: ensayo de un diccionario de traductores. Valladolid: Universidad de Valladolid.

Round, Nicholas 1993: 'Libro Llamado Fedrón'. Plato's 'Phaedo'translated by Pero Díaz de Toledo. London: Tamesis.

Ruiz Casanova, José Francisco 2000: Aproximación a una historia de la traducción en España. Madrid: Cátedra.

Santoyo, Julio-César 1987: Teoría y crítica de la traducción: Antología. Bellaterra: Universitat Autònoma de Barcelona.

Santoyo, Julio-César 1996: Bibliografía de la traducción en español, catalán, gallego y vasco. León: Universidad de León.

Santoyo, Julio-César 1999: Historia de la Traducción: quince apuntes. León: Universidad de León.

Santoyo, Julio-Cesar 2002: Review of Negotiating the frontier: Translators and intercultures in Hispanic history by Anthony Pym. In Target 14:1, 185-188.

Tannen, Deborah 2007: Talking Voices. Repetition, Dialogue, and Imagery in Conversational Discourse. Second Edition. Cambridge: Cambridge University Press.

Toury, Gideon 1995: Descriptive Translation Studies and beyond. Amsterdam/Philadelphia: Benjamins.

Vandeweghe, Willy/Vandepitte, Sonia/van de Velde, Marc 2007: Introduction: A Linguistic 'Re-turn' in Translation Studies? In Belgian Journal of Linguistics 21/1, $1-10$.

Wolf, Michaela (ed.): Übersetzen - Translating - Traduire: Towards a 'Social Turn'? Münster/Hamburg/Berlin/Vienna/London: LIT.

Wolf, Michaela/Fukari, Alexandra (eds.) 2007: Constructing a Sociology of Translation. Amsterdam/Philadelphia: Benjamins. 